\title{
Perancangan Pembelajaran Fisika tentang Rangkaian Seri dan Paralel untuk Resistor Menggunakan Understanding by Design (UbD)
}

\author{
Sinta Pertiwi ${ }^{1}$, Debora Natalia Sudjito ${ }^{1,3,}$, Ferdy Semuel Rondonuwu ${ }^{2,3}$ \\ ${ }^{1}$ Jurusan Pendidikan Fisika \\ ${ }^{2}$ Jurusan Fisika \\ ${ }^{3}$ Pusat Studi Pendidikan Sains, Teknologi, dan Matematika (e-SisTeM) \\ Fakultas Sains dan Matematika, Universitas Kristen Satya Wacana, Salatiga, Jawa Tengah 50711 \\ *email korespondensi: debora.natalia@staff.uksw.edu
}

\begin{abstract}
ABSTRAK
Mengajar adalah membuat belajar terlaksana. Oleh karena banyaknya materi yang dicakup dalam suatu pembelajaran, maka langkah pembelajaranpun sudah tidak disesuaikan lagi dengan tujuan dan evaluasi pembelajaran. Understanding by Design (UbD) adalah sebuah pendekatan pembelajaran yang menekankan pada tujuan pembelajaran itu sendiri. UbD diterapkan sebagai alternatif solusi untuk memperbaiki kualitas pembelajaran dengan cara mensinkronkan tujuan, langkah, dan evaluasi pembelajaran. UbD digunakan untuk membuat desain pembelajaran fisika tentang rangkaian resistor seri dan paralel. Desain yang telah dibuat terdiri dari tiga stage dimana stage 1 merupakan tujuan pembelajaran, stage 2 merupakan evaluasi pembelajaran, dan stage 3 merupakan langkah pembelajaran. Tujuan dari pembelajaran ini yaitu (1) mahasiswa dapat menjelaskan karakteristik resistor yang disusun seri dan paralel, serta (2) mahasiswa dapat menganalisa besaran-besaran fisis (arus, tegangan, dan hambatan). Assesment dalam pembelajaran ini meliputi (1) mahasiswa dapat mengukur arus menggunakan amperemeter yang dipasang seri terhadap resistor dan mengukur tegangan dengan voltmeter yang dipasang paralel terhadap resistor, dan juga (2) mahasiswa dapat menghitung arus, tegangan, hambatan menggunakan persamaan. Langkah-langkah pembelajaran yang dilakukan oleh pengajar berisi kegiatan-kegiatan yang dilakukan selama pembelajaran berlangsung. Setelah dibuat desain pembelajaran, maka dibuatlah lembar review yang akan diserahkan kepada reviewer untuk dikaji. Desain pembelajaran ini mempunyai acuan yang jelas, dimana antara tujuan pembelajaran, evaluasi dan langkah pembelajaran saling terkait. Berdasarkan dari desain yang telah dibuat, lembar review dan hasil review oleh reviewer didapatkan bahwa desain yang dibuat dengan Understanding by Design (UbD) ini mampu mengatasi kelemahan-kelemahan yang ada pada dosen saat mengajar fisika dasar di kelas.
\end{abstract}

Kata-kata kunci: expert review; rangkaian resistor seri dan paralel; Understanding by Desain (UbD)

\section{PENDAHULUAN}

Tugas pokok seorang guru adalah mengajar. Mengajar adalah membuat belajar terlaksana (teaching as making learning possible) (Munthe, 2014). Hal ini dapat diwujudkan jika ada usaha yang memanfaatkan berbagai strategi, metode, dan teknik guna memungkinkan tercapainya kompetensi/hasil belajar tertentu, dalam arti ada perubahan dari tidak bisa menjadi bisa, dari tidak mampu menjadi mampu (Sari dkk., 2016). Kompetensi yang harus dicapai peserta didik dinyatakan dalam tujuan pembelajaran (Prawiradilangga, 2009). Tujuan pembelajaran dapat tercapai jika perancang pembelajaran dapat menciptakan suatu pembelajaran yang kondusif sehingga peserta didik merasa nyaman dan termotivasi dalam proses belajarnya. Hal ini menjadi salah satu tugas pokok guru (Pratiwi dkk., 2015).

Pada umumnya pembelajaran untuk suatu topik dirancang dengan cara membuat tujuan pembelajaran, kemudian langkah pembelajaran, selanjutnya baru membuat evaluasi pembelajaran. Saat membuat tujuan pembelajaran, banyaknya materi yang dicakup dalam sebuah topik membuat pengajar seringkali lebih fokus pada penyampaian semua materi tanpa mempertimbangkan materi mana yang benar-benar dibutuhkan siswa sesuai kompetensi yang diterapkan oleh kurikulum. Akibatnya kalimat tujuan pembelajaran dibuat berdasarkan cakupan materi (khususnya yang ditulis di buku-buku pegangan), bukan berdasarkan konsep kunci yang dibutuhkan siswa untuk mencapai kompetensi. Langkah pembelajaranpun tidak disesuaikan lagi dengan tujuan dan evaluasi pembelajaran. Langkah pembelajaran dilakukan berdasarkan rutinitas mengajar, artinya metode dan media belajar yang digunakan tidak bervariasi dan tidak disesuaikan dengan karakteristik siswa dan tujuan pembelajaran. Dalam membuat evaluasi, pada umumnya pengajar langsung memberikan soal-soal yang didapat dari buku dan terkadang 
tidak disesuaikan dengan tujuan dan langkah pembelajaran. Hal ini menyebabkan tujuan, langkah, dan evaluasi pembelajaran tidak lagi saling terkait lalu pada akhirnya membuat siswa kebingungan memahami materi dan hasil evaluasi yang diperoleh kurang memuaskan (As'ari, 2016).

Salah satu materi dalam perkuliahan Fisika Dasar yang perlu dikuasai oleh mahasiswa Pendidikan Fisika adalah rangkaian resistor (seri dan paralel). Berdasarkan hasil wawancara dengan dosen pengampu mata kuliah Fisika Dasar di salah satu universitas swasta di Jawa Tengah, terdapat kesulitan yang dihadapi dalam mengajarkan materi rangkaian resistor seri dan paralel yaitu: (1) konsep mengenai arus masih abstrak bagi mahasiswa sehingga dibutuhkan visualisasi yang membantu siswa mengerti, (2) perlu sesuatu yang dapat menarik minat mahasiswa untuk berlatih mengerjakan soal, dan (3) waktu tatap muka yang masih kurang jika mahasiswa hanya mau mengerjakan soal di kelas. Padahal berdasarkan arsip rancangan pembelajaran yang dimiliki oleh dosen pengampu, tujuan, evaluasi, dan langkah pembelajaran sudah saling terkait. Namun ternyata, berdasarkan hasil evaluasi mahasiswa, nilai mereka cukup rendah. Hal ini berarti masih banyak mahasiswa yang kesulitan dalam memahami materi. Hal ini menunjukkan bahwa perlu adanya perbaikan kualitas pembelajaran.

Perbaikan kualitas pembelajaran dapat dilakukan dengan meninjau kembali desain pembelajaran yang dibuat (Fox, 2012). Salah satu alternatif solusi yang bisa digunakan untuk membuat desain pembelajaran yang mensinkronkan tujuan, langkah, dan evaluasi pembelajaran adalah Understanding by Design (UbD). UbD adalah sebuah pendekatan pembelajaran yang menekankan pada tujuan pembelajaran itu sendiri. Dalam hal ini guru harus merancang tujuan dan bagaimana tujuan itu betul-betul dicapai (As'ari, 2016). Istilah Understanding by Design (UbD) sama halnya dengan Backward Design atau desain mundur. Dalam pendekatan Understanding by Design (UbD), Backward Design lebih fokus pada pembelajaran dan pemahaman siswa (Wiggins and Mc Tighe, 2005). Perbedaan mendasar UbD dan desain pembelajaran lainnya adalah pada urutan perancangan evaluasi pembelajaran dan langkah pembelajaran. Biasanya guru merancang pembelajaran mulai dari menentukan tujuan pembelajaran, kemudian langkah pembelajaran, lalu evaluasi pembelajaran; namun dalam UbD, perancangan dimulai dari tujuan pembelajaran, kemudian menyusun evaluasi pembelajaran dan kemudian baru merencanakan langkah pembelajaran.

Penelitian yang telah dilakukan oleh Almaseid (2017) berjudul The Impact of Using Understanding by Design (UbD) Model On $8^{\text {th }}$-Grade Student's Achievemen in Science, dilakukan karena adanya permasalahan yang terjadi dalam pembelajaran, salah satunya masih digunakannya model tradisional dimana pengajar fokus dalam transfer informasi sehingga belum bisa meningkatkan keahlian siswa berpikir kritis dan kreatif. Penelitian ini mengatakan bahwa UbD dinilai efektif dalam pembelajaran, terkhusus untuk materi sains. UbD bahkan direkomendasikan sebagai salah satu desain pembelajaran efektif yang bisa digunakan di kelas.

Penelitian ini menyajikan bagaimana menerapkan Understanding by Design (UbD) digunakan untuk membuat desain pembelajaran fisika tentang rangkaian resistor seri dan paralel sebagai altenatif desain pembelajaran yang dapat digunakan di kelas. Penelitian ini bertujuan untuk membuat desain pembelajaran fisika tentang rangkaian resistor seri dan paralel menggunakan Understanding by Design (UbD). Manfaat dari penelitian ini yaitu memberi contoh desain pembelajaran fisika tentang rangkaian resistor seri dan paralel menggunakan Understanding by Design (UbD) yang dapat diimplementasikan dalam proses pembelajaran.

\section{PROSEDUR KERJA}

Desain pembelajaran tentang rangkaian resistor seri dan paralel dibuat menggunakan Understanding by Design (UbD). Ada tiga stage dalam UbD, yaitu Stage 1: tujuan pembelajaran, Stage 2: evaluasi pembelajaran, dan Stage 3 : langkah pembelajaran. Template UbD yang digunakan dapat dilihat pada Tabel 1. Template ini lebih sederhana dibandingkan dengan template yang dibuat oleh Wiggins dan Mc Tighe (2005), karena mereka membuat desain Understanding by Design (UbD) yang disesuaikan dengan konteks pembelajaran di Eropa, sedangkan desain yang dibuat dalam penelitian ini disesuaikan dengan konteks pembelajaran di Indonesia. Template yang dibuat oleh Wiggins dan Mc Tighe (2005) sangat detail mengikuti pertanyaan-pertanyaan penggiring yang esensinya mengacu ke kurikulum pendidikan Eropa, sedangkan pada penelitian ini template yang digunakan menyesuaikan Kurikulum 2013 yang dipakai di Indonesia, di mana langkah pembelajaran mengintegrasikan pendekatan saintifik. 
Tabel 1. Template Desain UbD

STAGE 1: Tujuan Pembelajaran

1.

2.

3.

STAGE 2: Evaluasi Pembelajaran

Tujuan:

Assesment :

Evaluasi:

Tujuan:

Assesment :

Evaluasi:

Tujuan:

Assesment :

Evaluasi:

\section{Alokasi waktu:}

Kegiatan 1:

Kegiatan 2:

Kegiatan 3:

Tujuan pembelajaran pada Stage 1 ini dibuat berdasarkan konsep-konsep dasar yang harus dikuasai peserta didik. Tujuan pembelajaran ini dibuat dengan cara menentukan kata-kata kunci penting dalam materi rangkaian resistor seri dan paralel, yaitu rangkaian resistor seri, rangkaian resistor paralel, arus, tegangan, dan hambatan. Setelah mendapatkan kata-kata kunci yang sesuai, kemudian apa yang diinginkan untuk dikuasai mahasiswa dinyatakan dalam kalimat yang mengandung kata kerja operasional yang diambil dari Taksonomi Bloom sebagai rumusan tujuan pembelajaran.

Evaluasi pembelajaran pada Stage 2 berisi assesment dan soal evaluasi. Assesment dibuat berdasarkan tujuan pembelajaran dan berisi kalimat yang menyatakan performa siswa yang menunjukkan apakah siswa sudah menguasai materi yang disampaikan atau belum. Soal evaluasi dibuat mengacu pada assesment untuk menguji pemahaman siswa akan materi. Soal evaluasi menggunakan pertanyaanpertanyaan terbuka yang memungkinkan siswa berpikir kritis dan menuangkannya dalam jawaban mereka.

Langkah pembelajaran pada Stage 3 merupakan kegiatan pembelajaran yang dilakukan oleh pengajar dan peserta didik. Langkah pembelajaran ini dirancang untuk membekali siswa dalam memahami materi, sehingga pada akhirnya mereka bisa mengerjakan soal evaluasi untuk mencapai tujuan pembelajaran.

Setelah desain pembelajaran dibuat, lembar review dibuat untuk melihat keterkaitan tujuan pembelajaran, evaluasi, dan langkah pembelajaran pada desain. Lembar review berisi pertanyaanpertanyaan, penilaian oleh reviewer, dan juga tanggapan reviewer. Pertanyaan-pertanyaan dalam lembar review mencakup seputar keterkaitan antara tujuan dan evaluasi, keterkaitan antara tujuan dan langkah pembelajaran, keterkaitan antara evaluasi dan langkah pembelajaran, kedalaman materi, metode yang digunakan, media yang digunakan, pertanyaan atau perintah dalam langkah pembelajaran sudah bisa membuat siswa berpikir kritis atau belum, alokasi waktu, dan juga apakah soal evaluasi sudah menggunakan pertanyaan terbuka atau tidak. Penilaian oleh reviewer dilakukan dengan memilih salah satu option antara ya, cukup, dan tidak. Reviewer juga dipersilakan menulis saran dan komentar mereka di kolom tanggapan.

Desain pembelajaran diberikan pada tiga reviewer, yaitu para pengajar fisika untuk di review menggunakan panduan pada lembar review. Data hasil review yang terkumpul dianalisa menggunakan teknik analisa deskriptif kualitatif kemudian dipakai sebagai bahan pertimbangan untuk revisi desain pembelajaran sampai diperoleh desain final. Skema prosedur penelitian dapat dilihat pada Gambar 1. 


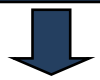

Lembar review dibuat

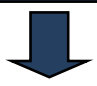

Desain pembelajaran direview oleh reviewer menggunakan panduan lembar review

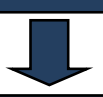

Hasil review ditelaah

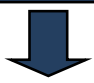

Desain pembelajaran direvisi sampai menghasilkan desain final

Gambar 1. Prosedur penelitian

\section{HASIL DAN DISKUSI}

Desain pembelajaran Understanding by Design (UbD) tentang rangkaian resistor seri dan paralel yang dibuat meliputi tiga Stage. Stage 1 merupakan tujuan dari desain pembelajaran yang telah dibuat. Tujuan dari pembelajaran ini yaitu (1) mahasiswa dapat menjelaskan karakteristik resistor yang disusun seri dan paralel, serta (2) mahasiswa dapat menganalisa besaran-besaran fisis (arus, tegangan, dan hambatan). Tujuan ini dipilih karena disesuaikan dengan konsep dasar yang ada pada rangkaian listrik itu yang harus dikuasai oleh mahasiswa yaitu karakteristik rangkaian seri dan paralel, sebelum berlanjut ke materi yang lebih kompleks. Jika mahasiswa sudah menguasai konsep rangkaian seri dan paralel, mereka akan dapat menyelesaikan persoalan rangkaian gabungan seri dan paralel yang lebih banyak digunakan dalam rangkaian listrik.

Stage 2 merupakan assesment dan evaluasi yang mengacu pada tujuan pembelajaran. Assesment ini meliputi (1) mahasiswa dapat mengukur arus menggunakan amperemeter yang dipasang seri terhadap resistor dan mengukur tegangan dengan voltmeter yang dipasang paralel terhadap resistor, dan juga (2) mahasiswa dapat menghitung arus, tegangan, hambatan menggunakan persamaan. Setelah assesment ditentukan, dibuatlah soal evaluasi yang terdiri dari beberapa soal yang mengacu pada assesment.

Pada assesment yang pertama yaitu mahasiswa dapat mengukur arus menggunakan amperemeter yang dipasang seri terhadap resistor dan mengukur tegangan dengan voltmeter yang dipasang paralel terhadap resistor, menggunakan rangkaian pada Gambar $\mathbf{2}$ sebagai evaluasinya. Rangkaian ini terdiri dari 6 resistor yang disusun secara seri dan paralel. Pada gambar tersebut terdapat 7 sub pertanyaan meliputi menghitung dan mengukur hambatan pengganti, arus total, arus yang mengalir pada resistor, dan tegangan pada resistor dan titik-titik tertentu. Assesment ini dipilih karena disesuaikan dengan tujuan yang ingin dicapai, seperti pada tujuan yang pertama mahasiswa dapat menjelaskan karakteristik rangkaian resistor yang disusun seri dan paralel. Karakteristik rangkaian tersebut meliputi arus dan tegangannya, maka pada assesmentnya mahasiswa diminta untuk bisa mengukur arus dan tegangan pada resistor dengan benar. Oleh sebab itu soal evaluasi yang dibuat adalah tentang pengukuran arus dan tegangan pada resistor.

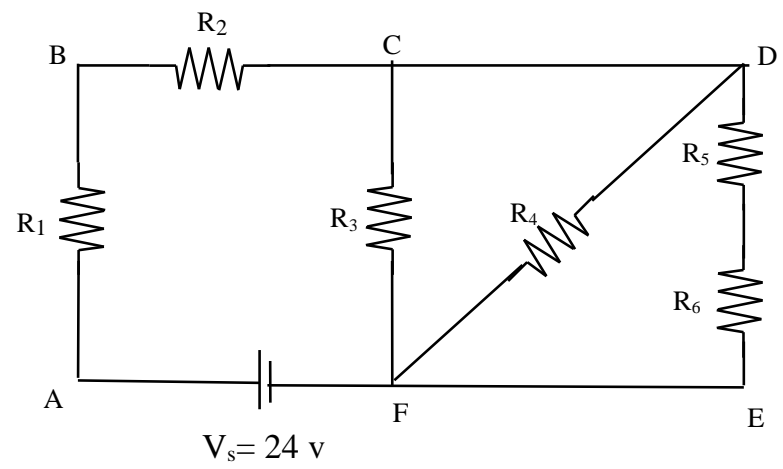

Gambar 2. Rangkaian resistor pada soal evaluasi 1. 
Pada assesment kedua yaitu mahasiswa dapat menghitung arus, tegangan, dan hambatan pada resistor. Pada evaluasi kedua disediakan 3 resistor yang telah diketahui besar hambatan masing-masing dan besar hambatan penggantinya. Pada evaluasi ini juga telah disediakan gambar bentuk rangkaiannya, namun hanya 2 resistor saja yang terdapat pada gambar (lihat Gambar 3). Dari soal tersebut mahasiswa diminta memasang resistor yang tersisa pada rangkaian supaya hambatan penggantinya berubah sesuai pertanyaan dalam soal. Untuk assesment yang kedua disesuaikan dengan tujuan kedua yaitu mahasiswa dapat menganalisa besaran-besaran fisis (arus, tegangan, dan hambatan), sehingga pada assesmentnya mahasiswa diminta untuk menghitung arus, tegangan, dan hambatan pada resistor. Oleh sebab itu, soal evaluasi adalah tentang perhitungan besaran fisis.

Tabel 2. Rangkaian resistor pada soal evaluasi 2

\begin{tabular}{|c|c|}
\hline Sebelum Dipasang & Sesudah Dipasang \\
\hline $\mathrm{V}_{\mathrm{s}}=24 \mathrm{v}$ & $\mathrm{\textrm {R } _ { 2 }}$ \\
\hline
\end{tabular}

Stage 3 merupakan langkah pembelajaran yang di dalamnya berisi kegiatan-kegiatan yang dilakukan pengajar dan peserta didik selama proses pembelajaran berlangsung. Langkah pembelajaran berisi penjelasan tentang penyusunan rangkaian resistor seri dan paralel, cara pemasangan amperemeter, voltmeter, dan ohmmeter untuk mengukur $I, V, R$, cara baca skala multimeter, dan juga menghitung besar $I, V, R$ dengan persamaan. Pembelajaran yang dilakukan yaitu dengan membagi mahasiswa ke dalam beberapa kelompok, lalu mahasiswa diberikan penjelasan singkat mengenai cara penyusunan amperemeter dan voltmeter pada rangkaian resistor. Amperemeter disusun seri terhadap rangkaian dan voltmeter dipasang paralel terhadap rangkaian. Setelah mengetahui cara penyusunan amperemeter dan voltmeter, kemudian dilanjutkan penjelasan mengenai cara membaca skala multimeter. Lalu mahasiswa dijelaskan mengenai rangkaian seri dan paralel. Rangkaian seri dan paralel digambar kemudian masing-masing kelompok diberi tugas untuk menyusun alat sesuai dengan gambar yang telah diberikan. Selanjutnya besar arus dan tegangan pada resistor diukur dengan amperemeter dan voltmeter. Kemudian mahasiswa ditugaskan menghitung besar tegangan dan arus yang mengalir pada tiap-tiap resistor dengan persamaan. Langkah pembelajaran tadi dirancang supaya mahasiswa dapat menemukan perbedaan rangkaian seri dan paralel melalui pengukuran langsung dan perhitungan. Pada akhir pembelajaran diberikan latihan soal untuk memperdalam pemahaman peserta didik.

Setelah desain pembelajaran selesai dibuat, lembar review untuk panduan reviewer dibuat. Lembar review ini memuat kajian terhadap banyak aspek. Keterkaitan antara tujuan pembelajaran, evaluasi, dan langkah pembelajaran menjadi salah satu aspek penting dalam lembar review. Selain itu, dalam lembar review ini juga terdapat aspek kesesuaian alokasi waktu, ketepatan pemilihan media pembelajaran, keefektifan instruksi atau perintah atau pertanyaan yang digunakan dalam pembelajaran, dan kedalaman materi rangkaian resistor seri dan paralel yang digunakan dalam langkah pembelajaran.

Hasil review dari para reviewer, berupa tanggapan dan saran, dikaji sehingga ada yang diterima dan ada juga yang tidak. Berdasarkan hasil review, tujuan pembelajaran (1) sesuai dengan evaluasi (1) dan tujuan pembelajaran (2) sesuai dengan evaluasi (2). Untuk langkah pembelajaran, menurut reviewer, langkah pembelajaran (1) sesuai dengan tujuan pembelajaran (1) dan langkah pembelajaran (2) dan (3) sudah sesuai dengan tujuan pembelajaran (2).

Soal-soal evaluasi pada langkah pembelajaran termasuk ke dalam tipe pertanyaan terbuka dalam hal menguji pengetahuan mahasiswa, sehingga pengajar dapat mengetahui mahasiswa mana saja yang sudah mulai dapat berpikir kritis. Hal ini didukung dengan adanya soal evaluasi pengecoh pada assessment kedua.

Review berikutnya adalah tentang kedalaman materi. Kedalaman materi rangkaian resistor seri dan paralel dalam pembelajaran yang dibuat, menurut reviewer belum cukup untuk mahasiswa tingkat pertama. Dalam pembelajaran masih diperlukan penambahan materi rangkaian $\Delta$ (delta) dan $Y$ (bintang). Tanggapan ini tidak diterima karena materi rangkaian delta-bintang merupakan pengembangan dari 
rangkaian seri dan paralel, sedangkan desain pembelajaran ini ditujukan untuk materi dasar tentang rangkaian seri dan paralel. Jika mahasiswa sudah memahami rangkaian seri dan paralel, maka untuk pengembangan skill mereka, baru perlu diberikan rangkaian delta-bintang.

Hasil review yang berkaitan dengan pertanyaan dan perintah yang digunakan untuk membuat mahasiswa berpikir kritis, diberi saran supaya langkah pembelajaran tidak hanya berupa instruksi saja, namun diberikan juga pertanyaan-pertanyaan penggiring agar mahasiswa dirangsang untuk mencoba. Tanggapan ini diterima. Instruksi diperbaiki dengan menambahkan pertanyaan penggiring agar materi dapat dipahami mahasiswa seperti yang terekam pada Tabel $\mathbf{3}$.

Tabel 3. Perbaikan instruksi langkah pembelajaran

\begin{tabular}{|c|c|c|}
\hline \multicolumn{2}{|r|}{ Sebelum Diperbaiki } & Setelah Diperbaiki \\
\hline 1. & $\begin{array}{l}\text { Mahasiswa diminta mengukur } V \text { pada masing- } \\
\text { masing } R \text { dengan voltmeter pada rangkaian } \\
\text { mulai dari rangkaian dengan dua resistor } \\
\text { kemudian ditambah satu resistor menjadi tiga } \\
\text { resistor, untuk menyelidiki terdapat perbedaan } \\
\text { besar atau tidak. }\end{array}$ & $\begin{array}{l}\text { Guru menyediakan sebuah rangkaian dengan dua } \\
\text { resistor untuk diukur. Setelah diukur, rangkaian } \\
\text { tersebut akan ditambah satu resistor untuk diukur } \\
\text { kembali. Guru bertanya kepada siswa: } \\
\text { - Berapakah arus yang mengalir pada rangkaian } \\
\quad 1 \text { dan rangkaian 2? }\end{array}$ \\
\hline 2. & $\begin{array}{l}\text { Mahasiswa diminta mengukur } I \text { pada masing- } \\
\text { masing } R \text { dengan amperemeter pada rangkaian } \\
\text { mulai dari rangkaian dengan dua resistor } \\
\text { kemudian ditambah satu resistor menjadi tiga } \\
\text { resistor, untuk menyelidiki terdapat perbedaan } \\
\text { besar atau tidak }\end{array}$ & $\begin{array}{l}\text { - Berapa tegangan pada rangkaian } 1 \text { dan } \\
\text { rangkaian 2? } \\
\text { Bagaimana besarnya arus rangkaian } 1 \\
\text { dibandingkan dengan rangkaian 2? } \\
\text { - Bagaimana besarnya tegangan rangkaian } 1 \\
\text { dibandingkan dengan rangkaian 2? }\end{array}$ \\
\hline
\end{tabular}

Selanjutnya, terkait media pembelajaran dan alokasi waktu, reviewer menyatakan bahwa media pembelajaran berupa alat praktikum menjadi media yang cocok diterapkan pada langkah pembelajaran ini dan waktu yang dialokasikan juga cukup jika diterapkan dalam pembelajaran riil.

Penelitian mengenai desain pembelajaran tentang rangkaian seri dan paralel telah banyak dilakukan. Penelitian yang dilakukan Fajar (2013) menyatakan bahwa pre-eksperimental design dengan bentuk one group pretest-posttest design untuk menguji signifikansi penggunaan model pembelajaran inkuiri pada materi listrik untuk siswa ternyata dapat menurunkan miskonsepsi materi listrik. Namun dari grafik yang diperoleh, masih terdapat miskonsepsi, baik pada pre-test maupun pada post-test. Jadi perlu dipertimbangkan model lain yang mampu mengatasi miskonsepsi peserta didik. Desain UbD dapat digunakan sebagai salah satu alternatif desain pembelajaran karena desain UbD yang telah dibuat sudah mempertimbangkan cara mengatasi miskonsepsi peserta didik yaitu dengan perancangan tujuan dan evaluasi terlebih dahulu sebelum membuat langkah pembelajaran langkah pembelajaran sehingga apa yang diinginkan oleh guru terhadap peserta didik dapat terpenuhi. Namun dalam penelitian ini belum dipertimbangkan antisipasi terhadap miskonsepsi peserta didik, sehingga hal ini perlu dikembangkan pada penelitian selanjutnya.

Selain itu, secara spesifik, beberapa penelitian dengan Understanding by Design (UbD) telah dilakukan untuk mengetahui implementasi Understanding by Design (UbD) untuk pembelajaran di kelas. Penelitian tersebut telah dilakukan oleh Almaseid (2017) berjudul The Impact of Using Understanding by Design (UbD) Model on $8^{\text {th }}$-Grade Student's Achievement in Science, yang mengatakan bahwa UbD dinilai efektif dalam pembelajaran, terkhusus untuk materi sains, karena pada pre-test sebelum mengaplikasikan UbD dan post-test setelah mengaplikasikan UbD memperlihatkan peningkatan nilai siswa. Penelitian lain terkait UbD juga dilakukan oleh Yurtseven (2016) dalam penelitiannya yang berjudul Understanding by Design (UbD) in EEL Teaching: The Investigation of Student' Foreign Language Learning Motivation and Views. Penelitian ini juga menggunakan pre-test sebelum mengaplikasikan UbD dan post-test setelah mengaplikasikan UbD dan didapatkan hasil yang meningkat. Penelitian-penelitian ini mendukung penggunaan UbD pada pembelajaran tentang rangkaian resistor seri dan paralel. Kelebihan UbD adalah pengajar dapat memastikan keterkaitan tujuan pembelajaran, evaluasi pembelajaran, dan langkah pembelajaran sehingga saat pembelajaran dilakukan, siswa memahami mengapa mereka harus mempelajari dan menguasai materi itu, sehingga pada akhirnya nilai mereka baik dan itu berarti tujuan pembelajaran tercapai.

Setiap desain pembelajaran memiliki kelebihan dan kelemahan masing-masing yang dapat membuat desain tersebut semakin diperbaharui terus menerus menjadi lebih baik. Kelebihan dari desain UbD yang telah dibuat yaitu tujuan pembelajaran, evaluasi pembelajaran, dan langkah pembelajaran saling 
terkait sehingga mampu mengatasi kelemahan-kelemahan yang ada pada dosen saat mengajar fisika dasar di kelas. Selain kelebihan ada juga kelemahan desain UbD ini yaitu dalam pembuatan desain ini belum mengantisipasi miskonsepsi peserta didik.

\section{KESIMPULAN}

Desain pembelajaran tentang rangkaian resistor seri dan paralel menggunakan Understanding by Design (UbD) telah dibuat dalam penelitian ini. Berdasarkan hasil review dari para pengajar fisika yang menjadi reviewer desain ini, desain ini dapat digunakan menjadi salah satu alternatif desain pembelajaran untuk memperbaiki kualitas pendidikan. Hal penting yang mendasarinya adalah dalam UbD ditekankan bahwa tujuan pembelajaran, evaluasi pembelajaran, langkah pembelajaran harus saling terkait. Jadi penggunaan UbD dalam mendesain pembelajaran direkomendasikan untuk para pengajar.

\section{DAFTAR PUSTAKA}

Almaseid, T.F. 2017. The Impact of Using Understanding by Design (UbD) Model On $8^{\text {th }}$-Grade Student's Achievemen in Science. Ministryof Education, United Arab of Emirates (UAE). Vol. 13, No. 4

As'ari, A.R. 2016. Penggunaan Backward Design dalam Merancang Pembelajaran Matematika Yang Bernuansa Observation-Based Learning. FMIPA Universitas Negeri Malang.

Fajar, D.M., dan Supardi, Z.A.I. 2013. Pengaruh Penggunaan Model Pembelajaran Inkuiri (Inquiry Learning) Terhadap Penurunan Miskonsepsi Pada Materi Listrik Dinamis Kelas X SMAN 2 Jombang. UNESA. Vol. 02 , No. 02

Fox, Bruce E., J. Doherty, John. 2012. Design to Learn, Learn to Design: Using Backward Design For Information Literacy Instruction. Northern Arizona University. Vol. 5, Issue 2

Munthe, Bermawi. 2014. Desain Pembelajaran. Yogyakarta: PT Pustaka Insan Madani.

Pratiwi, E., Rondonuwu, F.S., dan Noviandini, D. 2015. Desain Masalah pada Topik Rangkaian Listrik untuk Metode Pembelajaran Berbasis Masalah. Pendidikan Fisika Universitas Kristen Satya Wacana. Vol. 6, No. 1

Prawiradilangga, D.S. 2009. Prinsip Disain Pembelajaran. Jakarta: Kencana.

Sari, N.R., Noviandini, D., dan Ayub, M.R.S.S.N. 2016. Implementasi Model Pembelajaran POE (Prediction Observation Explanation) Untuk Meningkatkan Pemahaman Siswa dan Keaktifan Siswa Materi Rangkaian Listrik Sederhana. Pendidikan Fisika Universitas Kristen Satya Wacana. http://repository.uksw.edu/handle/123456789/10825

Wiggins, G., and Mc Tighe, J. 2005. Understanding by Design: Extended 2nd Edition. Alexandria, VA: ASCD.

Yurtseven, N. and Altun, S. 2016. Understanding by Design (UbD) in EEL Teaching: The Investigation of Student' Foreign Language Learning Motivation and Views. Yildiz Technical University, Istanbul, Turkey. Vol. 4, No. 3 